MS, Vol. 7, No. 1, January - June 2008, pp. 13-25

ISSN 0975-3311

https:/ / doi.org/ 10.12725/ mjs.12.2

\title{
HIGHLY SELECTIVE DERIVATIVE SPECTROPHOTOMETRIC DETERMINATION OF VANADIUM(V) IN STEELS, MINERALS AND SOIL SAMPLES
}

\author{
Anitha Varghese* \& A. M. A. Khadar**
}

\begin{abstract}
A simple, selective and sensitive spectrophotometric method has been developed for the determination of trace amounts of Vanadium $(V)$ in acetic acid medium using a newly synthesised reagent acetoacetanilide salicyloylhydrazone (AASH). The molar absorptivity and Sandell's sensitivity of the coloured species were found to be $1.20 \times 10^{4} \mathrm{~L} \mathrm{~mol}^{-1}$ $\mathrm{cm}^{.1}$ and $4.2 \mathrm{ng} \mathrm{cm}^{-2}$ respectively. Beer's low is obeyed in the range $0.3-3.0 \mu \mathrm{g} \mathrm{mL} L^{-1}$ of vanadium(V) at $405 \mathrm{~nm}$. The stoichiometry of the complex was found to be 1:1 (V(V): AASH). A highly selective first order derivative spectrophotometric method for the determination of vanadium is also reported. A calibration graph was derived by measuring first derivative amplifudes at $430 \mathrm{~nm}$ (trough depth). The metal ions
\end{abstract}

* Department of Chemistry, Christ College,Hosur Road, Bangalore - 560029. Email:anitha.varghese@christcollege.edu Phone: 9900505883

** Department of Chemistry, Mangalore University, Mangalagangothri, Mangalore - 574 199, India.Email:amakhader@yahoo.com 
which are normally associated with vanadium in minerals and alloys do not interfere. The developed procedure has been successfully applied for the trace level determination of vanadium in steels, minerals and soil samples.

\section{Introduction}

The determination of trace amounts of vanadium is of great interest because of the high toxicity of its compounds and its increasing industrial applications [1]. Environmental scientists have declared vanadium as a potentially dangerous chemical pollutant that can play havoc with the productivity of plants, crops and the entire agricultural system. High amounts of vanadium are said to be present in crude petroleum and heavy oil. Power and heat producing plants using fossil fuels cause the discharge of vanadium into the environment [2]. Vanadium has also been reported as the index element in urban environment pollution, especially air pollution. Acute vanadium poisoning is characterized by nervous depression, coughing, vomiting, diarrhoea, negative effects on lever and kidney and increased risk of lung cancer [3]. Hence the accurate determination of vanadium at trace levels using simple and rapid methods is of great importance. Various analytical techniques used for the determination of vanadium in environmental samples include NAA [4], ICP-AES [5] and AAS [6] and spectrophotometry. Spectrophotometric methods occupy special position due to their simplicity, less expensive instrumentation and high sensitivity. Kinetic spectrophotometric methods based on the catalytic action of vanadium( $M$ ) on the oxidation of organic compounds with inorganic reactant (eg. bromate or periodate) are highly sensitive but are generally lacking simplicity or a long time is necessary to complete the reaction [7-10]. The most widely used reagent for vanadium (M) determination is pyridyl azo resorcinol (PAR), but many of these methods suffers from limitations. such as serious interference from $U(\mathrm{VI}), \mathrm{Ti}(\mathrm{IV}), \mathrm{Zr}(\mathrm{V})$, and $\mathrm{Nb}(\mathrm{M})$ ions, the delay in colour development and also significant absorbance for the reagent blank solution [1 1-13]. Other reagents have been suggested for the spectrophotometric determination of vanadium include 1, 10-phenanthroline [14], ferron [15], 2-(2-quinolylazo)-5-diethylaminophenol [16], methdilazine hydrochloride [17], picolinealdehyde salicyloylhydrazone [18], 2,4-dihydrxyacetophenone benzoylhydrazone and pyridine [19] and pyrogallol [20]. Most of these methods suffer from limitations such as tedious and time consuming extraction $[15,18]$, low selectivity $[16]$, reduction to lower oxidation state followed by extraction [19] or lack of sensitivity [14,17].

In the present investigation we report a simple, selective and non-extractive derivative spectrophotometric determination of vanadium(M using a newly synthesized reagent acetoacetanilide salicyloylhydrazone (AASH) in acetic acid medium. The 
derivatisation of the spectral profiles enhances the selectivity of the method as closely overlapped absorption bands of the interfering ions become resolved [21]. The distinct advantage of the proposed method is that the commonly associated metal ions especially $\mathrm{Fe}, \mathrm{Mo}, \mathrm{Mn}, \mathrm{Co}, \mathrm{Cr}$ and $\mathrm{Ni}$ could be tolerated in considerable excess. The method has been successfully applied for the determination of vanadium in steels, minerals and soil samples.

\section{Experimental}

\section{Apparatus}

A Shimadzu 1601 UVNIS. Spectrophotometer equipped with $1.0 \mathrm{~cm}$ quartz cells was used for all spectral measurements. The instrumental parameters were optimised and the best results were obtained with a scan speed $370 \mathrm{~nm} / \mathrm{min}$., slit width of $1 \mathrm{~nm}$ and $\Delta \lambda=2 \mathrm{~nm}$ for the first order derivative mode in the wavelength range $350-650 \mathrm{~nm}$. A Systronics $\mu \mathrm{pH}$ system 362 was used for $\mathrm{pH}$ measurements.

\section{Reagents}

All chemicals used were of analytical grade. A stock solution of vanadium( $M$ $\left(1000 \mu \mathrm{gmL}^{-1}\right)$ was prepared by dissolving an accurately weighed amount of sodium metavanadate (s. d. fine-chem. Ltd. India) in distilled water and made up to the mark in a $100 \mathrm{~mL}$ volumetric flask. This stock solution was standardised [22] and working solutions were prepared by diluting the stock solution to an appropriate volume. Solutions of the studied interfering ions of suitable concentrations were prepared using A.R. grade reagents. A $0.1 \%$ solution of AASH was prepared in ethanol. A $10 \mathrm{M}$ acetic acid solution was used throughout the study.

\section{Synthesis of AASH}

Acetoacetanilide salicyloylhydrazone was synthesised by refluxing equimolar amounts of acetoacetanilide and salicyloylhydrazide in ethanolic medium for 2 hours. The resulting hydrazone was recrystalised from ethanol (m.p. $=196^{\circ} \mathrm{C}$, yield, $75 \%$ ). IR spectra of AASH $(\mathrm{KBr})$. showed bands at $3271 \mathrm{~cm}^{-1}\left(\mathrm{v}_{\mathrm{NH}}\right), 3413 \mathrm{~cm}^{-1}\left(\mathrm{v}_{\mathrm{OH}}\right)$, $1647 \mathrm{~cm}^{-1}\left(v_{\mathrm{C}=0}\right)$, and $1543 \mathrm{~cm}^{-1}\left(v_{\mathrm{C}=N}\right)$. The signals in ' $\mathrm{H}$ NMR (DMSO-d spectrum of AASH are assigned as follows. The $-\mathrm{OH}$ proton appeared as a singlet at $\delta, 11.07$ integrating for one proton. The two $-\mathrm{NH}$ proton signals appeared in the region $\delta, 10.21-10.33$. The aromatic protons resonated at $\delta, 6.97-7.92$ as multiplets (Figure 1). 


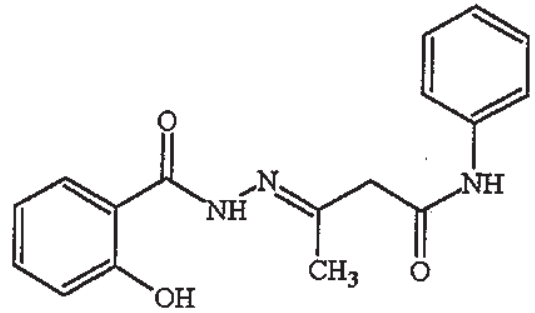

Fig 1 : Structure of AASH

\section{General procedure}

Aliquots of the solution containing 3.0-30.0 $\mu$ g of vanadium $(M$ were transferred into a series of $10.0 \mathrm{~mL}$ calibrated volumetric flasks. To these were added AASH $(0.1 \%, 2 \mathrm{~mL})$ and acetic acid $(10 \mathrm{M}, 4 \mathrm{~mL})$ and the contents were diluted to the mark with distilled water and mixed well. The absorbance of the coloured species was measured at $405 \mathrm{~nm}$ against the corresponding reagent blank.

The first order derivative spectra were recorded with reference to the reagent blank in the wavelength range $350-600 \mathrm{~nm}$. The concentration range applicable to derivative mode was $0.2-3.5 \mu \mathrm{g} \mathrm{m}^{-1}$ of vanadium $M$. In the derivative spectrum trough depth (TD) at $430 \mathrm{~nm}$ was measured from the zero line of the spectrum to determine its dependence on the metal ion concentration. Calibration graph was constructed by plotting the derivative amplitudes against the concentration of vanadium $M$ ions.

\section{Analysis of vanadium steel}

An accurately weighed amount of alloy steel sample $(0.5 \mathrm{~g}$.) was dissolved completely in $10 \mathrm{~mL}$ of aqua regia by slow heating on a sand bath and then heated to fumes of oxides of nitrogen. After it was cooled, sulphuric acid $(5 \mathrm{~mL}, 1: 1)$ was added and evaporated almost to dryness. The residue left over was treated with $20 \mathrm{~mL}$ of distilled water and filtered. The filtrate was diluted to $50 \mathrm{~mL}$ with distilled water. Potassium permanganate solution $(0.002 \mathrm{M})$ was added drop wise till the solution attained pink colour. It was allowed to stand for $5 \mathrm{~min}$, and then warmed and oxalic acid solution $(0.0025 \mathrm{M})$ was added slowly with constant stirring till the disappearance of pink colour. The solution was diluted to $100 \mathrm{~mL}$ with distilled water. Citrate solution was used to mask iron wherever necessary. Suitable aliquots of sample solutions were analysed for vanadium according to the procedure for first derivative spectrophotometry. 


\section{Analysis of vanadium in ilmenite mineral samples}

Finely powdered ilmenite (about $0.5 \mathrm{~g}$.) was weighed accurately into a silica crucible and fused with sodium hydrogen sulphate $(10 \mathrm{~g}$.) until the sample was completely decomposed. The melt was cooled and dissolved in $(2 \mathrm{M}, 25 \mathrm{~mL})$ sulphuric acid, filtered. The filtrate was treated with potassium permanganate and oxalic acid solution as described for the analysis of vanadium steels and diluted to $100 \mathrm{~mL}$ with distilled. Citrate solution was used to mask iron wherever necessary. Suitable aliquots of sample solutions were analysed according to the procedure for first derivative spectrophotometry.

\section{Determination of vanadium in soil samples}

A known amount of $(1 \mathrm{~g}$.) air dried homogenized soil samples, spiked with known amounts of vanadium $(M$ was taken and brought into solution by following the standard method recommended by Jackson [23]. A suitable aliquot of the solution was taken and analysed using the procedure outlined earlier.

\section{Results and Discussion}

Preliminary investigations have shown that AASH reacts with vanadium $M$ in acetic acid medium at room temperature to form an yellow coloured species, which shows maximum absorbance at $405 \mathrm{~nm}$. The reagent blank had negligible absorbance at this wavelength. The absorption spectra of the coloured species against reagent blank under the optimum conditions are presented in Figure 2.

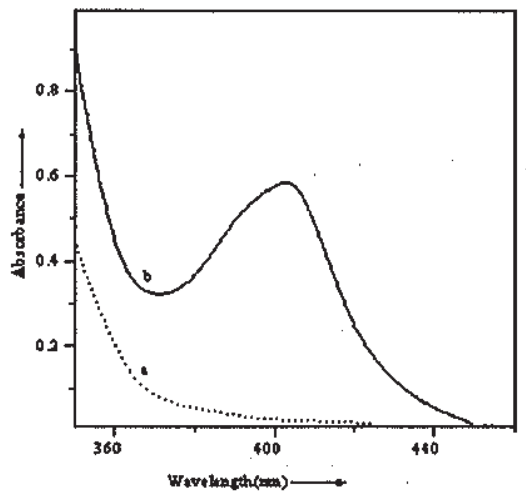

Fig 2 : Absorption (zero order) spectra of (a) reagent blank vs distilled water and (b) V(M-AASH complex Nanadium, $2.4 \mu \mathrm{g} \mathrm{mL}^{-1}$ ) vs reagent blank., each containing $2 \mathrm{~mL}$ of $0.1 \%$ AASH and $4 \mathrm{~mL}$ of $10 \mathrm{M}$ acetic acid in a total volume of $10 \mathrm{~mL}$. 


\section{Effect of acidity}

The effect of different acids on the absorbance of vanadium $M$-AASH species has been investigated using $\mathrm{H}_{3} \mathrm{PO}_{4}, \mathrm{HCl}, \mathrm{HNO}_{3}, \mathrm{H}_{2} \mathrm{SO}_{4}$ and $\mathrm{CH}_{3} \mathrm{COOH}$. It was observed that colour formation of the complex was slow in phosphoric acid medium. The colour intensity was less in nitric acid, hydrochloric acid and sulphuric acid media. $\mathrm{CH}_{3} \mathrm{COOH}$ medium ( $3 \mathrm{M}-6 \mathrm{M}$ ) was found to be optimum for this analytical work because of higher sensitivity and longer stability of the coloured species (figure 3). Hence $4 \mathrm{~mL}$ of $10 \mathrm{M} \mathrm{CH}_{3} \mathrm{COOH}$ in a total volume of $10 \mathrm{~mL}$ was preferred for further analytical studies.

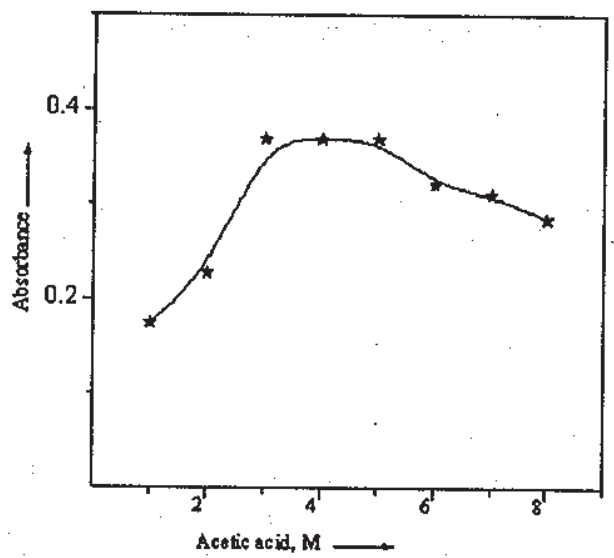

Fig 3 : Effect of acetic acid concentration on the absorbance of V(M)-AASH species (vanadium, $1.6 \mu \mathrm{g} \mathrm{mL}^{-1}$ )

\section{Effect of reagent concentration}

Different molar excess of AASH were added to fixed metal ion concentration and absorbance were measured according to the standard procedure. A 10-fold molar excess of AASH is found to be necessary for maximum and constant colour development for $1 \mu \mathrm{g} \mathrm{mL}^{-1}$ of vanadium(M). Excess of reagent had no effect on the sensitivity and stability of the complex. For up to $35 \mu \mathrm{g}$ of vanadium(M, the addition of $2 \mathrm{~mL}$ of $0.1 \%$ AASH was found to be sufficient to complete the reaction. Under the optimum conditions the absorbance of the complex was found to remain constant at least for 6 hours at room temperature, which showed that these coloured species are stable. 


\section{Analytical parameters}

The molar absorptivity and Sandell's sensitivity values of VM-AASH species calculated from Beer's law data are $1.20 \times 10^{4} \mathrm{~L} \mathrm{~mol}^{-1} \mathrm{~cm}^{-1}$ and $4.2 \mathrm{ng} \mathrm{cm}^{-2}$ respectively. Beer's law is obeyed in the range of $0.3-3.0 \mu \mathrm{g} \mathrm{mL}^{-1}$. The linear regression analysis of absorbance, $[\mathrm{A}]$ at $\lambda_{\operatorname{mox}}$ of the complex versus metal ion concentrations $\left(\mu \mathrm{g} \mathrm{mL}^{-1}\right)$, shows a good linear fit (Table 1$)$.

Table 1: Analytical characteristics of V(V)-AASH complex

\begin{tabular}{|l|l|l|}
\hline Parameters & $\begin{array}{l}\text { Normal } \\
405 \mathrm{~nm}\end{array}$ & $\begin{array}{l}\text { First derivative } \\
430 \mathrm{~nm}\end{array}$ \\
\hline Molar absorptivity $\left(\mathrm{L} \mathrm{mol}^{-1} \mathrm{~cm}^{-1}\right)$ & $1.20 \times 10^{4}$ & - \\
Sandell's sensitivity $\left(\mathrm{ng} \mathrm{cm}^{-2}\right)$ & 4.2 & - \\
Detection limit $\mathrm{C}_{\mathrm{t}}(\mathrm{k}=3)\left(\mu \mathrm{gmL}^{-1}\right)$ & $7.6 \times 10^{-2}$ & $2.8 \times 10^{-2}$ \\
Quantitation limit $\mathrm{C}_{\mathrm{Q}}(\mathrm{k}=10)\left(\mu \mathrm{gmL}^{-1}\right)$ & $2.5 \times 10^{-1}$ & $9.5 \times 10^{-2}$ \\
Regression equation $(\mathrm{y})^{\circ}$ & & \\
Slope, $\mathrm{m}$ & 0.2354 & 0.0104 \\
Intercept, $\mathrm{c}$ & -0.008 & -0.0004 \\
Correlation coefficient, $\mathrm{r}$ & 0.9996 & 0.9998 \\
RSD\% & 1.14 & 0.92 \\
\hline
\end{tabular}

${ }^{\circ} y=m x+c$ where $y$, absorbance/peak height/ trough depth; $m$, slope; $x$, analyte concentration $\left(\mu \mathrm{gmLl}^{-1}\right)_{i} c$, intercept.

First order derivative spectra of V(M-AASH complex shows a small peak at $395 \mathrm{~nm}$, a trough at $430 \mathrm{~nm}$ and a cross over point at $405 \mathrm{~nm}$, corresponding to the $\lambda_{\text {mox }}$ of the complex (Figure 4). The derivative amplitudes measured at $430 \mathrm{~nm}$ were found to be proportional to the concentration of vanadium $M$. The characteristics of calibration graph are given in Table 1. The high value of correlation coefficient and closeness of the intercept to zero show that calibration graphs are linear and obey Beer's law. The derivative method allowed the determination of vanadium $(M)$ in the range $0.2-3.5 \mu \mathrm{g} \mathrm{m}^{-1}$ at $430 \mathrm{~nm}$. 


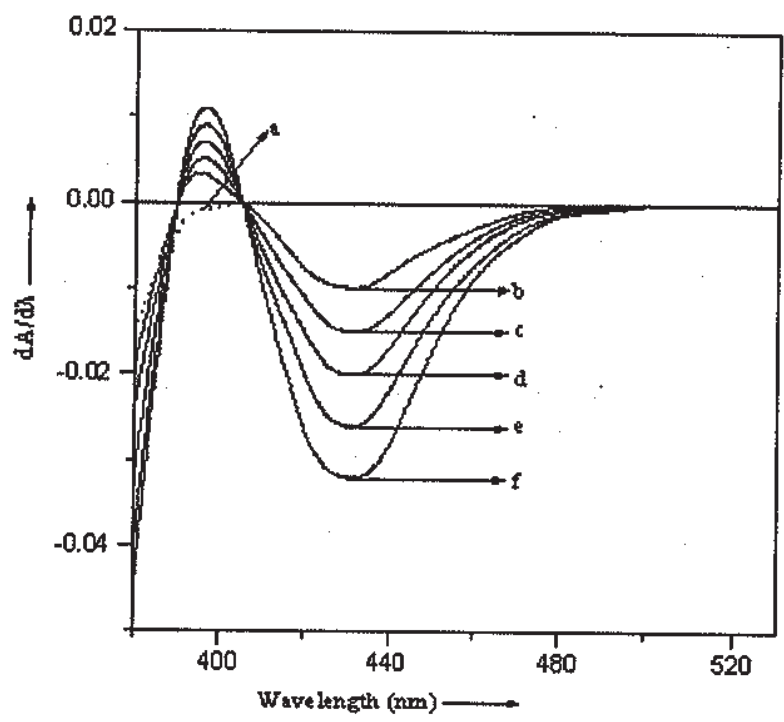

Fig 4 : First order derivative spectra of V(M-AASH system: (a) Reagent blank vs distilled water, $(b-f)$ contain increasing amounts of VM up to $3.5 \mu \mathrm{gmL}^{-1}$ and all other conditions are as described in figure 2 .

Limit of detection $C_{L}(k=3)$ and limit of quantification $C_{Q}(k=10)$ in normal and derivative modes as defined by IUPAC, are reported in Table 1. The precision of the method in different modes, reported as relative standard deviafions, RSD determined by measuring absorbance or derivative amplitude of five replicate samples containing $1.5 \mu \mathrm{g} \mathrm{mL}^{-1}$ of vanadium $M$.

\section{Stoichiometry and stability constant}

The stoichiometry of the complex was investigated by Job's continuous variation method and mole ratio method and was found to be 1:1 (NM:AASH). The stability constant of complex was determined by limiting logarithmic method [24] and was found to be $2.86 \times 10^{7}$. The nature of the species was investigated by passing an aliquot of the solution through a cation (Amberlite IR 120) and an anion (Amberlite IRA 400) exchange resin. Only cation exchange resin retained the coloured species, indicating the cationic nature of the species.

Isolation of the coloured species was done by extraction into chloroform phase. The reagent was found to be not soluble in the solvent. The extract on slow 
evaporation yielded a solid product. Characterisation of isolated species was done by $I R$ and NMR spectral analysis. The $-\mathrm{OH}$ and $-\mathrm{NH}$ proton signals in the ${ }^{\prime} \mathrm{H}$ NMR spectra of both the complexes remained more or less in the same positions as in the free ligands indicate that neither groups are deprotonated or involved in coordination. In the IR spectrum, appearance of $v_{\mathrm{OH}}$ and $v_{\mathrm{NH}}$ bands in the same position as in the free ligands suggesting non-involvement of these groups in bonding. The band due to $v_{C=N}$ and $v_{C=0}$ merged and appeared at $1600 \mathrm{~cm}^{-1}$ indicating involvement of these groups in coordination. Band due to $\mathrm{VO}_{2}$ is observed at $970-975 \mathrm{~cm}^{-1}$. Broad band appeared around $3400-3500 \mathrm{~cm}^{-1}$ indicates coordinated water molecules. The most probable structural formula of the chelate is proposed in figure 5 .

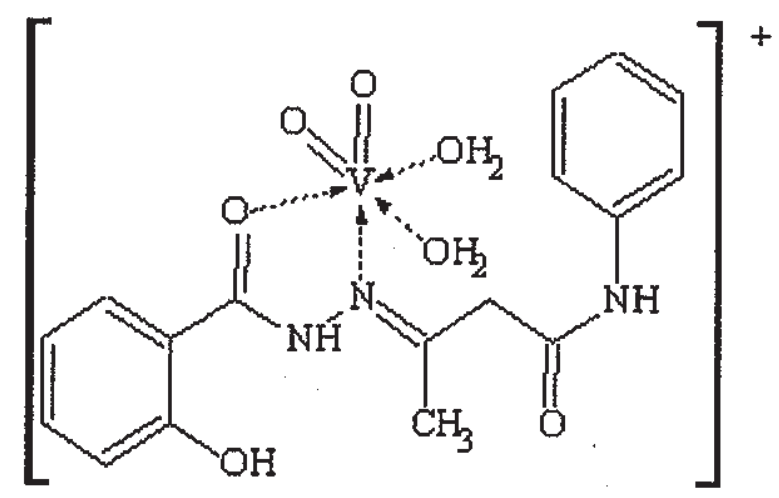

Fig 5 : The probable structural formula of VM-AASH species.

\section{Effect of diverse ions}

To assess the usefulness of the proposed method the effect of diverse ions on the trace level determination of vanadium $\left(1.5 \mu \mathrm{g} \mathrm{mL}^{-1}\right)$ has been investigated in normal and in first derivative modes. The tolerance limit was taken to be the amount that caused a $\pm 3 \%$ change in absorbance. The tolerance limits of the foreign ions tested are given in Table 2. Alkali and alkaline earth metal ions and a large number of anions did not interfere even when present in large excess. Cations like Co(II), $\mathrm{Ni}(I), \mathrm{Mn}(\mathrm{II}), \mathrm{Mo}(\mathrm{VI})$, and $\mathrm{Cr}(\mathrm{III})$ which are usually associated with vanadium containing samples did not interfere in both zero order and derivative modes. The most serious interference was from Zr(IV) ions due to the complex formation with AASH. The measurement in the first derivative mode at $430 \mathrm{~nm}$ (zero-crossing 
point of $\mathrm{Zr}(\mathrm{IV})$-AASH complex) increases the tolerance limit of $\mathrm{Zr}(\mathrm{IM})$ up to 20 -fold excess. Thus the selectivity of the method is considerably enhanced by recording spectra in the derivative mode without any pre-separation or addition of masking agents.

Table 2 : Tolerance limit of diverse ions in the determination of $1.5 \mu \mathrm{g} \mathrm{mL}^{-1}$ Vanadium(M)

\begin{tabular}{|c|c|c|c|}
\hline lons & $\begin{array}{l}\text { Tolerence limit } \\
\left.\text { ( } \mu \mathrm{g} \mathrm{mL}^{-1}\right)\end{array}$ & lons & $\begin{array}{l}\text { Tolerence limit } \\
\left(\mu \mathrm{gL} \mathrm{mL}^{-1}\right)\end{array}$ \\
\hline Co(II) & 800 & $\mathrm{Zr}(\mathrm{IV})$ & $5(30)^{b}$ \\
\hline$M n(11)$ & 700 & $\mathrm{Al}(\mid 11)$ & 800 \\
\hline Ni(lil) & 750 & Mo(VI) & 500 \\
\hline $\mathrm{Cr}(111)$ & 300 & $\mathrm{Cu}(\mathrm{ll})$ & 500 \\
\hline $\mathrm{Na}(l)$ & 3000 & $T i(M)$ & 600 \\
\hline$K(1)$ & 3000 & Chloride & 5500 \\
\hline $\mathrm{Ca}(\mathrm{ll})$ & 2000 & iodide & 2000 \\
\hline $\operatorname{Sr}(11)$ & 1500 & bromide & 3000 \\
\hline $\mathrm{Ba}(\|)$ & 2500 & nitrate & 5000 \\
\hline$M g(I I)$ & 1500 & phosphate & 2500 \\
\hline $\mathrm{Pb}(\mathrm{ll})$ & 500 & sulphate & 3500 \\
\hline $\mathrm{Zn}(\mathrm{ll})$ & 500 & fluoride & 3000 \\
\hline $\mathrm{Hg}(\mathrm{ll})$ & 400 & oxalate & 1000 \\
\hline $\mathrm{Fe}(\|1\|)$ & $70(1000)^{a}$ & EDTA & 400 \\
\hline
\end{tabular}

o In the presence of $3 \mathrm{mg} \mathrm{mL}^{-3}$ of citrate; ${ }^{6}$ Measurement in the derivative mode

\section{Analytical applications}

The proposed method was applied to the quantitative determination of vanadiumM in steel and ilmenite samples. Based on the better sensitivity and selectivity measurement of derivative amplitudes at $430 \mathrm{~nm}$ is recommended for the determination of vanadium in various samples. The results of the analysis presented in Table 3 are in good agreement with the certified values. The low relative standard deviation values for analysis of five replicates indicated good precision of the proposed methods. 
Table 3 : Determination of vanadium $(M)$ in vanadium steels and ilmenite

\begin{tabular}{|c|c|c|c|c|}
\hline \multirow{2}{*}{ Sample } & \multirow{2}{*}{ Composition \% } & \multicolumn{2}{|c|}{ Vanadium \% } & \multirow{2}{*}{ RSD \% } \\
\hline & & Certified & found a & \\
\hline $\begin{array}{l}\text { Vanadium } \\
\text { steel } \\
7110 \mathrm{~b}\end{array}$ & $\begin{array}{l}\mathrm{C}, 0.18 ; \mathrm{Si}, 0.34, \mathrm{Mn}, 0.33 ; \\
\mathrm{Ni}, 0.12 ; \mathrm{Cr}, 1.08 ; \mathrm{Mo}, 0.85 ; \\
\mathrm{V}, 0.87 ; \mathrm{Cu}, 0.22 ; \mathrm{P}, 0.018 ; \mathrm{S}, \\
0.012 ; \mathrm{Ti}, 0.11 ; \mathrm{Al}, 0.042 ; \\
\mathrm{B}, 0.0009 .\end{array}$ & 0.87 & 0.865 & 0.87 \\
\hline $\begin{array}{l}\text { Vanadium } \\
\text { steel } \\
\text { T032 b }\end{array}$ & $\begin{array}{l}\mathrm{C}, 0.56 ; \mathrm{Si}, 0.24 ; \mathrm{Mn}, 0.91 ; \\
\mathrm{Ni}, 0.23 ; \mathrm{Cr}, 1.03 ; \mathrm{Mo}, 0.03 ; \\
\mathrm{V}, 0.12 ; \mathrm{Cu}, 0.19 ; \mathrm{P}, 0.002 ; \\
\mathrm{S}, 0.018\end{array}$ & 0.12 & 0.121 & 1.00 \\
\hline $\begin{array}{l}\text { Diesteel } \\
\text { H13 Grade } \\
\text { EA } 0958\end{array}$ & $\begin{array}{l}\mathrm{C}, 0.370 ; \mathrm{Si}, 0.974 ; \\
\mathrm{Mn}, 0.364 ; \mathrm{P}, 0.024 ; \\
\mathrm{S}, 0.006 ; \mathrm{Cr}, 4.962 ; \mathrm{Ni} \\
0.318 ; \mathrm{Mo}, 1.254 ; \mathrm{V} \\
0.994\end{array}$ & 0.994 & 0.99 & 0.85 \\
\hline $\begin{array}{l}\text { Ilmenite } \\
Q \text { Grade }\end{array}$ & $\begin{array}{l}\mathrm{TiO}_{2}, 60.6 ; \mathrm{Fe}_{2} \mathrm{O}_{3}, 24.2 ; \\
\mathrm{FeO}_{3}, 9.3 ; \mathrm{Al}_{2} \mathrm{O}_{3}, 0.96 ; \\
\mathrm{MnO}, 0.39 ; \mathrm{Cr}_{2} \mathrm{O}_{3}, 0.12 ; \\
\mathrm{MgO}, 0.89 ; \mathrm{P}_{5}, 0.21 ; \\
\mathrm{V}_{2} \mathrm{O}_{5}, 0.15 ; \mathrm{ZrO}_{2}, 0.90 ; \\
\mathrm{SiO}_{2}, 0.41 ; \text { Rare earths, } \\
\text { traces 2.0. }\end{array}$ & 0.15 & 0.151 & 1.15 \\
\hline $\begin{array}{l}\text { Ilmenite } \\
\text { MKGrade }\end{array}$ & $\begin{array}{l}\mathrm{TiO}_{2}, 54.2 ; \mathrm{Fe}_{2} \mathrm{O}_{3}, 14.2 ; \\
\mathrm{FeO}_{2}, 26.6 ; \mathrm{Al}_{2} \mathrm{O}_{3}, 1.25 ; \\
\mathrm{MnO}, 0.4 ; \mathrm{Cr}_{2} \mathrm{O}_{3}, 0.07 ; \\
\mathrm{MgO}, 1.03 ; \mathrm{P}_{2} \mathrm{O}_{5}, 0.12 ; \\
\mathrm{V}_{2} \mathrm{O}_{5}, 0.16 ; \mathrm{ZrO}_{2}, 0.80 ; \\
\mathrm{SiO}_{2}, 0.68 ; \text { Rare earths, } \\
\text { traces } 0.34 .\end{array}$ & 0.16 & 0.162 & 1.08 \\
\hline
\end{tabular}

- Mean value of five determinations. 


\section{Statistical analysis of the results in comparison with the standard method.}

The results of the analysis of soil samples were compared statistically by the students t-fest and by the variance ratio F-test with those obtained by the reported method [25]. The students t-values and the variance ratio $F$-values did not exceed the theoretical values, indicating that there was no significant difference in accuracy and precision between proposed and reference method. The results are given in Table 4.

Table 4 : Determination of vanadium $(\mathrm{V})$ in soil samples

\begin{tabular}{|c|c|c|c|c|c|c|c|}
\hline \multirow[t]{2}{*}{ Sample } & \multirow{2}{*}{$\begin{array}{c}V(V) \\
\text { added } \\
m g ~ m L L^{-1}\end{array}$} & \multirow{2}{*}{$\begin{array}{l}\text { Proposed } \\
\text { methodo } \\
\mathrm{mg} \mathrm{mL}^{-1}\end{array}$} & \multirow[t]{2}{*}{ RSD \% } & \multirow{2}{*}{$\begin{array}{l}\text { Reference } \\
\text { methoda } \\
\text { mg ml }^{-1}\end{array}$} & \multirow[t]{2}{*}{ RSD \% } & \multicolumn{2}{|c|}{$\begin{array}{l}\text { Comparison with } \\
\text { the reference method }\end{array}$} \\
\hline & & & & & & F-test ${ }^{b}$ & t-test c \\
\hline Soil 1 & 1.60 & 1.61 & 1.36 & 1.59 & 1.17 & 1.34 & 1.52 \\
\hline Soil 2 & 2.40 & 2.41 & 0.82 & 2.42 & 0.78 & 1.10 & 1.11 \\
\hline
\end{tabular}

- Mean value of five determinations.

b Tabulated F-value for $(4,4)$ degree of freedom at $p(0.95)$ is 6.39 .

c Tabulated t-value for $(4,4)$ degree of freedom at $p(0.95)$ is 2.78 .

\section{Conclusion}

The proposed method offers the advantages of high sensitivity, selectivity and simplicity for the determination of vanadium $(M$ without the need for organic solvent extraction, pre-concentration or pre-separation. The proposed method can be used as an alternative method for the determination of trace amounts of vanadium in mineral, alloys, urine and soil samples as the associated metal ions in these materials do not interfere with the determination.

\section{Acknowledgements}

The authors thank Indian Rare Earths Ltd., Manavalkuruchi for supplying ilmenite and Visweswaraiah Iron and Steels Ltd. for the supply of vanadium steels. 


\section{References}

1. G. D. Clayton and F. E. Clayton, (1981) Patty's Indusrial Hygiene and Toxicology, Vol. 2A,

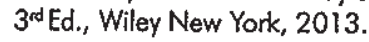

2. R. E. Eckardt, (1971) Arch. Environ. Health, 23, 166-167.

3. B. Venugopal and T. D. Luckey, (1979) Metal Toxicity in Mammals, Vol. 2, Plenum Press, New York, 220.

4. R. R. Greenberg and H. M. Kingston, (1983) Anal. Chem., 55, $1160-1165$.

5. H. Ogura and K. Oguma, (1994) Microchem. J., 49, 220-225.

6. J. Korkisch and H. Gross, (1973) Talanta, 20, $1153-1165$.

7. Ali A. Ensafi, M. K. Amini and M. Mazloum, (1999) Anal. Lett., 32, 1927-1937.

8. A. Safavi, M. R. Hormozi Nezhad and E. Shams, (2000) Anal. Chim. Acta, 409, 283-289.

9. H. Wang and A. Zhang, (1997) Microchem. J., 57, 218-223.

10. Ali A. Ensafi and A. Kazemzadeh, (1994) Anal. Chim. Acta, 298, 27-32.

11. K. Gavazov and A. Alexandrov, (2000) Talanta, 52, 539-544.

12. M. N. Abbas, A. M. Homoda and G. A. E. Mostafa, (2001) Anal. Chim. Acta, 436, 223-231.

13. G. Chakrapani, D. S. R Murthy, B. K. Balaji and R. Rangaswamy, (1993) Talanta, 40, $541-544$.

14. A. K. Bhadra, (1973) Talanta, 20, 13-19.

15. S. P. Arya and J. L. Malla, (1987) J. Indian Chem. Soc., LXIV, 777-778.

16. Q. Hu, X. Wu., G. Yang, Z. Huang and J. Yin, (2004), S. Afr. J. Chem., 57, 15-18.

17. M. B. Melwanki and J. Seetharamappa, (2000), Indian J. Chem., 39A, 1107-1109.

18. M. Gallego, M. Garcia-Vargas and M. Valcarcel, (1979) Microchem. J., 24, 143.149.

19. N. Agnihotri, R. Dass. and J. R. Mehta, (2003), Chem. Anal.(Warsaw), 48, 853-856.

20. N. Iranpoor, N. Maleki, S. Razi and A. Safavi, (1992), Talanta, 39, 281-284.

21. T. C. O' Hover, G. L. Green, (1976) Anal. Chem., 48, 312-318.

22. G. Charlot and D. Bezier, (1957), Quantitative Inorganic Analysis, Methuen and Co Ltd., London, p.623.

23. M.L. Jackson, (1965) Soil Chemical Analysis, Prentice Hall, Englewood Cliffs, 326.

24. R. L. Moore and R. C. Anderson, (1945) J. Amer. Chem. Soc., 67, 108.

25. M. J. Ahmed and S. Banoo, (1999) Talanta, 48, 1085-1094. 